\title{
Comparison of Conventional Uroflowmetry and New Smart, Self-Directed Outpatient Uroflowmetry in the Evaluation of Lower Urinary System Dysfunction in Children
}

\author{
Fatma Devrim $₫$ \\ Nida Dinçel ๑
}

\author{
Çocuklarda Alt Üriner Sistem Disfonksiyonunun \\ Değerlendirilmesinde Konvansiyonel Üroflovmetri ile \\ Hastayı Kendi Yönlendirilen Akıllı Üroflovmetri \\ Karşılaştırması
}

\begin{abstract}
Objective: Uroflowmetry is an essential noninvasive test with important diagnostic method in patients with initial diagnosis of lower urinary tract dysfunction. We aimed to compare the results of conventional uroflowmetry with those of the new smart "self-directed outpatient" uroflowmetry in children with suspected lower urinary tract dysfunction.

Methods: This cross-sectional study included children who had performed two sequential urinations in the same day recorded by conventional and smart "self-directed outpatient" uroflowmetry. Results of the measurements of maximum, and average urinary flow rates were recorded and compared.

Results: The mean difference between average urinary flow rates detected by both diagnostic methods was -1.7. The Bland-Altman plot showed that most of the data points were tightly clustered around the zero line of the difference between the measurements, with only $4 \%$ of the readings falling outside the $95 \%$ level of confidence. The mean difference between average urinary flow rates measured by both conventional and "self-directed outpatient" uroflowmetry was -4.5. The Bland-Altman plot showed that most of the data points were tightly clustered around the zero line of the difference between the measurements, with only $2 \%$ of the readings falling outside the $95 \%$ level of confidence.

Discussion: The maximum, and average urinary flow rates measured with "self-directed outpatient" uroflowmetry were statistically significantly higher compared to conventional uroflowmetry. These results could be due to the children being much shyer and being affected by the presence of someone in the room while urinating.

Conclusion: The maximum urinary flow rate and average urinary flow rate measured with "self-directed outpatient" uroflowmetry are higher compared to conventional uroflowmetry, which might ensure patient privacy.
\end{abstract}

Keywords: Uroflowmetry, maximum urinary flow rate, average urinary flow rate

öz

Amaç: Üroflovmetri alt üriner sistem disfonksiyonu ön tanılı hastalarda önemli tanısal değeri olan invazif olmayan bir tanı yöntemidir. Bu kesitsel çalıșmada alt üriner sistem disfonksiyonundan şüphenilen çocuklarda konvansiyonel üroflovmetri ile hastayı kendi yönlendiren akıllı üroflovmetri sisteminin sonuçların karşılaştırması amaçlanmıştır.

Yöntem: Kesitsel tipteki bu çalışmada konvansiyonel ve hastayı kendi yönlendiren akıllı üroflovmetri sistemi tarafından aynı günde iki ardışı işeme gerçekleştiren çocuklardan kayıt edilmiş olanlar dahil edilmiştir. Bu iki tanı yöntemi ile ölçülen maksimum idrar akış hızı ve ortalama idrar akış hızları karşılaştırıldı.

Bulgular: Her iki tanı yöntemi arasında ortalama idrar akıs hızları ortalaması arasındaki ortalama fark-1.7 olarak bulundu. Bland-Altman grafiği, konvansiyonel üroflovmetri ve hastayı kendi yönlendiren akıllı üroflovmetri sistemin ölçtüğü ortalama idrar akış hızları sonuçlarından oluşan veri noktalarının çoğunun ölçümler arasındaki farkın sıfır çizgisi etrafında sıkıca kümelendiğini ve okumaların sadece \%4'ünün \%95 güven düzeyinin dışında kaldığını gösterdi. Her iki tanı yöntemi arasında maksimum idrar akış hızları ortalaması arasındaki ortalama fark -4.5 olarak bulundu. Bland-Altman grafiği, konvansiyonel üroflovmetri ve hastayı kendi yönlendiren akıllı üroflovmetri sistemin ölçtügü maksimum idrar akış hızları sonuçlarından oluşan veri noktalarının çoğunun ölçümler arasındaki farkın sıfır çizgisi etrafında sıkıca kümelendiğini ve okumaların sadece \%2'sinin \%95 güven düzeyinin dışında kaldığını gösterdi

Sonuç: Hastayı kendi yönlendiren akıllı üroflovmetri cihazı ile ölçülen, maksimum idrar akıs hızı ve ortalama idrar akış hızları konvansiyonel üroflowmetriye göre daha yüksek bulundu. Bu özellikle çocukların utangaçığı ve idrar yaparken odada başka biri olmasından kaynaklandığı düşünülmüştür.
Received/Geliş: 11.04 .2020

Accepted/Kabul: 28.04.2020

Published Online/Online Yayın: 31.08.2020

Fatma Devrim SBÜ. İzmir Dr. Behcet Uz Çocuk Hastalıkları ve Cerrahisi Eğitim ve Araştırma Hastanesi, Çocuk Nefroloji Kliniği, İzmir - Turkey drfatmaslan@hotmail.com ORCiD: 0000-0001-9564-0489

N. Dinçel 0000-0002-1179-8519 SBÜ. İzmir Dr. Behcet Uz Çocuk Hastalıkları ve Cerrahisi Eğitim ve Araștırma Hastanesi, Çocuk Nefroloji Kliniği, Izmir, Türkiye

Anahtar kelimeler: Üroflovmetri, maksimum idrar akış hızı, ortalama idrar akış hızı 


\section{INTRODUCTION}

Lower urinary tract dysfunction (LUTD) is a common problem impairing the quality of life in children ${ }^{(1,2)}$. Medical history, physical examination, validated questionnaires, personal diaries for information about bladder/bowel functions and complete urinalysis are essential tests for the diagnosis of LUTD. In addition to these tests, uroflowmetry (UFM) is essential for diagnosis and effective treatment. Uroflowmetry is a noninvasive assessment test that can be easily applied to children ${ }^{(3,4)}$. Uroflowmetry is a technical measurement of urine flow rate requiring specialized equipment that measures the amount of urine and flow rate automatically. During the UFM test, the child voids into a particular container connected to a computerized system that records the velocity and caliber of urine flow ${ }^{(5)}$.

Uroflowmetry was reported to be a diagnostic tool which is comfortable for patients, relatively inexpensive, and time-efficient procedure which shows the natural voiding pattern in children ${ }^{(6-8)}$. It gives the results of voiding speed, voided volume, and voiding curve ${ }^{(9)}$. Uroflowmetry has a high sensitivity but low specificity, which might interfere with the diagnosis ${ }^{(10)}$.

The International Children's Continence Society (ICCS) guidelines recommend use of a qualitative classification divided into five curves. The bell-shaped curve is considered normal. Other types of curve patterns are a staccato, plateau, interrupted, and tower-shaped ${ }^{(11)}$. In adult studies, it was known that the uroflowmetric measurement of the first void urine could lead to unreliable results. Therefore it is recommended to obtain more than one uroflow curve ${ }^{(12)}$. In addition to the other tests, UFM is still an important test for diagnosis of non-neurogenic lower urinary tract dysfunction, showing a voiding phase abnormality ${ }^{(13)}$. Parameters derived from UFM are considered to be clinically reliable in the compatible children. Although the children try to be compliant, they have to void in a different room instead of the toilet mostly next to the parents, Moreover, knowing that the urine container would be emptied by a stranger might reduce their compli- ance to test and affect the results, mainly urine volume and curve shape. Therefore, the new "selfdirected outpatient" uroflowmetry might reduce all these false results arising from hesitating or being shy. In order to make an efficient micturition, complete relaxation of pelvic floor muscles should be maintained throughout the whole micturition process ${ }^{(14)}$. This functional interaction between detrusor contraction and pelvic floor relaxation for micturition is the cornerstone of the uroflowmetric measurement. Thus, the patients' compliance should be high and requires isolation from the environmental factors.

This cross-sectional study aimed to compare the results of conventional UFM and new smart "selfdirected outpatient" UFM which were performed at the children with suspected LUTD.

\section{MATERIAL and METHODS}

\section{Setting:}

Children who had the symptoms of LUTD were included in this cross-sectional study. In this study, we hypothesized that maximum urinary flow rate (Qmax) and average urinary flow rate (Qave) measurements with conventional uroflowmetry and smart "self-directed outpatient" uroflowmetry were not significantly different.

Before performing tests, a trained nurse gave information using visual items for 20 minutes to all the chilren. All children who had performed two sequential voids by conventional uroflowmetry (Itri Plus, Aymed, Turkey) and smart "self-directed outpatient" uroflowmetry (Uroscan Inoflow Smart Uroflowmetry, Aymed, Turkey) were included in the study. The children who were younger than seven years of age (this is the age for going to school, which they had to urinate by themselves) were taken together with their caregivers for the tests. All the patients who had performed both of the test results in the same day (maximum 3 hours between two tests) were included. Between both tests, the patients were recommended to take oral 500 to $1000 \mathrm{~mL}$ of liquid and recommended to go to the second test only if they did feel their bladder-like urinating. The 
printout forms of both of the devices were recorded for further analysis. Measurements of maximum urinary flow rate (Qmax) and average urinary flow rate (Qave) were recorded and compared for these two tests. The maximum urinary flow rate were defined as the values taken at the highest point of the flow curve discounting spike artifact at internal filtering set at $10 \mathrm{~Hz}$.

\section{Device:}

Smart, self-directed outpatient uroflowmetry (Uroscan Inoflow Smart Uroflowmetry, Aymed, Turkey) is a newly developed gravimetric uroflowmetry device that measures flow rate throughout a certain time interval. The Smart self-directed outpatient uroflowmetry helps the children with visual and auditory directions for starting the voiding and reports the results by terms of voiding time, flowtime, time to peak flow, peak flow rate, average flow rate, and voided volume. The inflow uroflowmetry enables the patient to complete the urination without the help of the nurse and protects the privacy of the patient and prevents the embarrassment of the especially adolescent patient.

The patients' Qmax and Qave measurements between two tests were compared within the group, and also further analysis was done after splitting the study according to the gender. The unadjusted raw data were compared for the two different UFMs.

The study was approved by the local ethics committee of the institution.

\section{Statistical Analysis}

Statistical analysis was performed by using the SPSS for Windows (SPSS, Inc, Chicago, III; 2001) and MedCalc version 12.3.0 (MedCalc Software bvba, Broekstraat 52, 9030 Mariakerke, Belgium). Paired t-test or Wilcoxon sign test was used to compare the mean measurements according to the tests of normality. Correlation was determined by the Spearman correlation coefficient, whereas the extent of the agreement was assessed with the Bland-Altman plot ${ }^{(15)}$. The level of significance was taken to be $p<0.05$.

\section{RESULTS}

One hundred patients who met the inclusion criteria were included in the study. Of the 100 patients, $41(41 \%)$ were male, while 59 (59\%) were female. The mean age of patients who participated in this

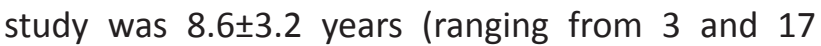
years).

The mean maximum urinary flow rates measured with conventional UFM and smart UFM were 17.3 \pm 11.4 (range: $0.00-65.5 \mathrm{~mL} / \mathrm{s}$ ) and $21.7 \pm 11.4$ (range: 2.8 to $53.7 \mathrm{~mL} / \mathrm{s}$ ), respectively. A Wilcoxon signed-rank test indicated that $\mathrm{Q}$ max values measured by smart UFM were statistically higher than the measurements with conventional UFM ( $Z=-4.033$; $p<0.001$ ). Indeed, median measurements were 20.25 and $15.55 \mathrm{~mL} / \mathrm{s}$ for smart UFM and conventional UFM, respectively. The mean average flow rates (Qaves) measured with conventional UFM, and smart UFM were $4.7 \pm 3.9 \mathrm{~mL} / \mathrm{s}$ (range: 0.3 to 16.3 ) and $6.4 \pm 5.5 \mathrm{~mL} / \mathrm{s}$ (range: 0.5-51.6), respectively. A Wilcoxon signed-rank test showed that Qave values measured by smart UFM were statistically higher than the measurements with conventional UFM ( $\mathrm{Z}=-3.1 ; \mathrm{p}<0.001)$.

There was a weak positive correlation for $Q$ max, and Qave measured with conventional UFM and smart UFM with a correlation coefficient of 0.78 $(p<0.001$; rS $(8)=.391$ for $Q$ max and rs $(8)=.297$, $\mathrm{p}=.003$ for Qave). Correlation graphics for $\mathrm{Q}$ max and $Q$ ave values measured with two methods were shown in Figure 1 (Figure 1a and 1b).

The average difference between the mean of both conventional UFM Q max and smart UFM Q max was-4.5 (\%95 Cl, -25.1 and 16.2). The BlandAltman plot showed that most of the data points were tightly clustered around the zero lines of the difference between the measurements, with only $2 \%$ of the readings ( $n=2)$ falling outside the $95 \%$ level of confidence (Figure 2a). Most of the (5 of 6 ) values beyond the limits of agreement were the values from the measurements made in female patients.

The average difference between the mean conventional UFM Qave and smart UFM Qave values was -1.7 (\%95 Cl, -13.8 and 10.4). The Bland-Altman 


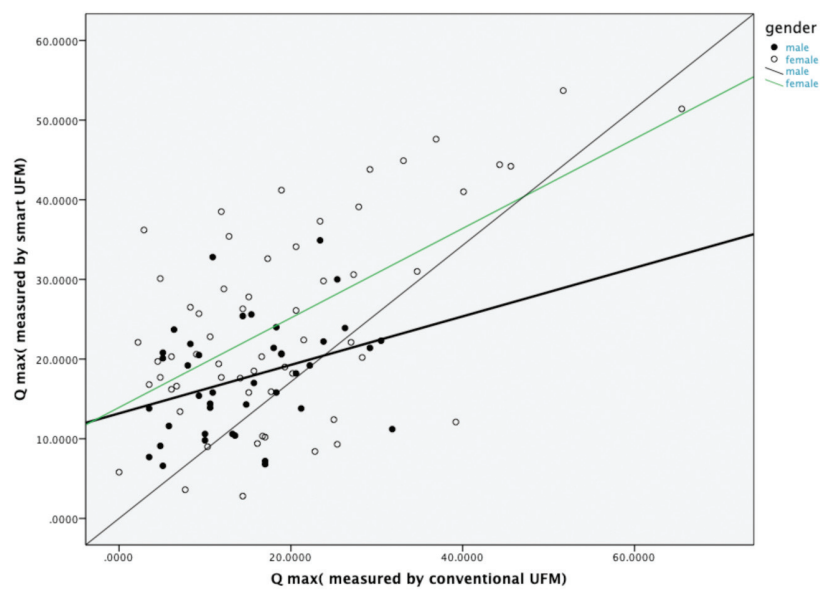

Figure 1a. The scatterplot graph of $Q_{\max }$ measured by two different methods in each gender.

The correlation between $Q_{\text {max }}$ measured by conventional and "self-directed outpatient" UFM $(r s(8)=0.391, p<0.001)$. In the boys group, there was a weak positive correlation for $Q_{\max }(r s(8)$ $=.383, p=.001)$ and in the girls group, there was a weak positive correlation for $Q_{\max }(r s(8)=.432, p=.001)$.

$Q_{\text {max }}:$ maximum urinary flow rate, UFM: uroflowmetry.

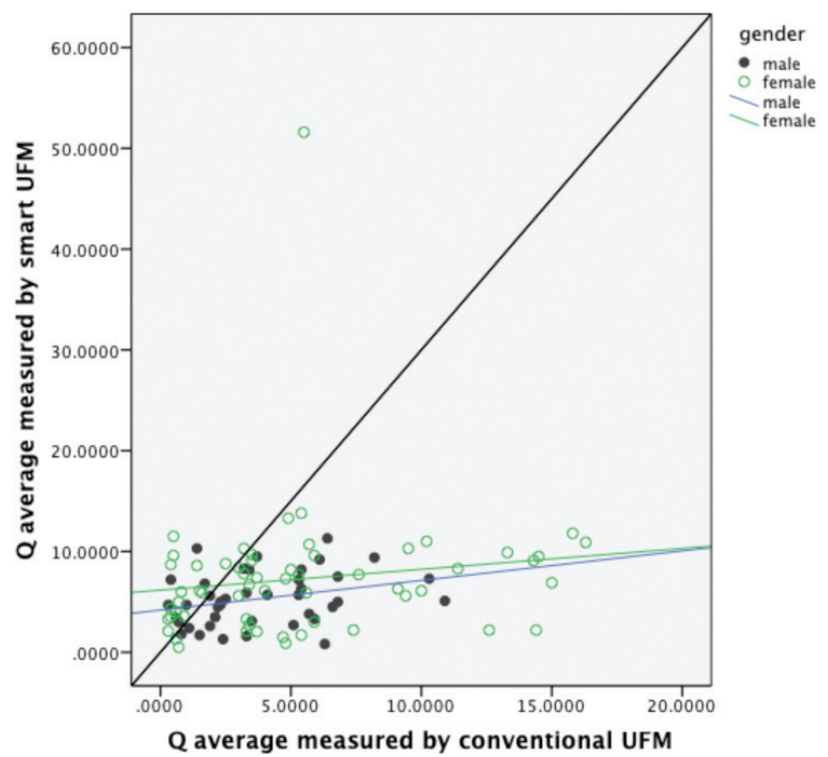

Figure 1b. The scatterplot graph of Qave measured by two different methods in each gender.

The correlation between Qave measured by conventional and smart, "self-directed outpatient" UFM (rs(8)=.297, $p=.003)$. In the boys and girls, there was a weak positive correlation for Qave $(r s(8)=.320, p=.041)$ and Qave $(r s(8)=0.293, p=.025)$ respectively.

Qave: average urinary flow rate, UFM: uroflowmetry at the children with suspected lower urinary tract dysfunction.

plot showed that most of the data points were tightly clustered around the zero lines of the diffe-

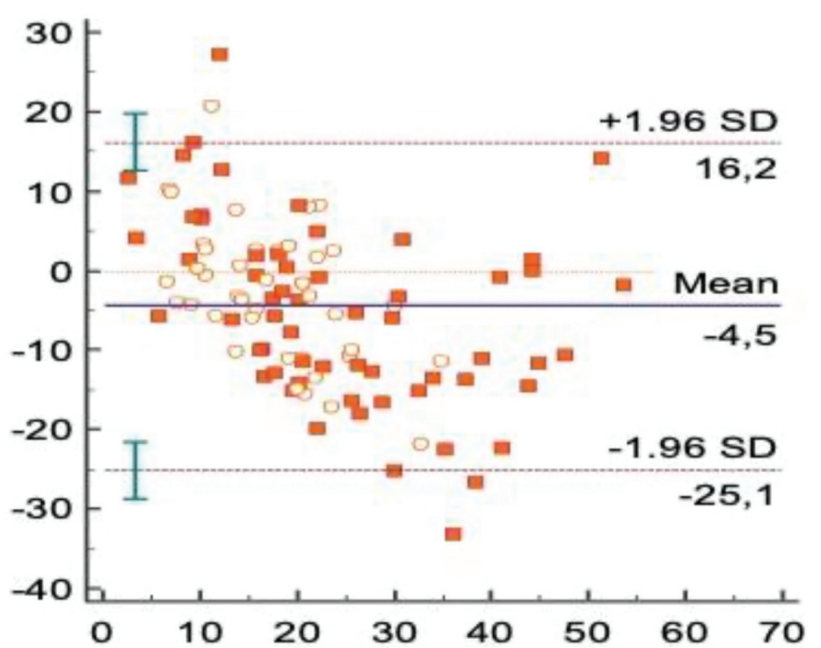

Figure 2a. The Bland-Altman plot of difference comparing $Q_{\text {max }}$ by conventional and smart, "self-directed outpatient" UFM.

The Bland-Altman plot of difference comparing $Q_{\max }$ measurements by conventional and smart UFM in the 100 readings, with mean difference and 95\% limits of agreement (red squares represent females, and white ones represent males).

$Q_{\max }$ : average urinary flow rate, UFM: uroflowmetry

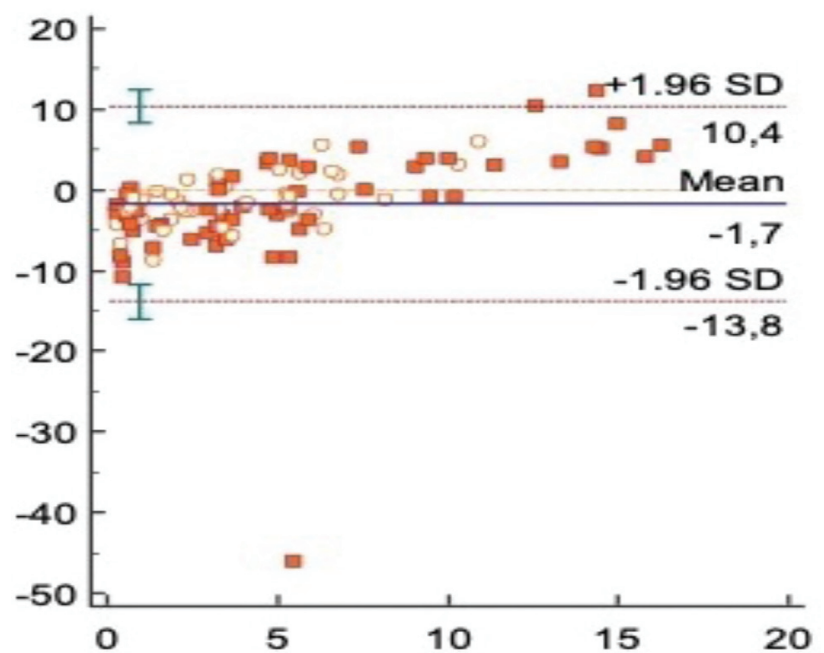

Figure $\mathbf{2 b}$. The Bland-Altman plot of difference comparing $\mathbf{Q}$ average by conventional and smart "self-directed outpatient" UFM.

The Bland-Altman plot of difference comparing $Q$ average measurements by conventional and smart "self-directed outpatient" UFM in the 100 readings, with mean difference and 95\% limits of agreement (red squares represent females, and white ones represent males)

$Q$ average: average urinary flow rate, UFM: uroflowmetry.

rence between the measurements, with only $4 \%$ of the readings $(n=4)$ falling outside the $95 \%$ level of 
confidence (Figure 2b).

Comparison of age, $Q$ max and $Q$ ave according to gender.

The mean age of girls was $8.8 \pm 3.4$ years ( 4 and 17 years), and the mean age of boys was $8.24 \pm 2.9$ years ( 3 and 14 years), without any significant difference between these two groups ( $p>0.05$ ).

In the male group, the mean maximum urinary flow rates ( $Q$ max) measured with conventional UFM and smart UFM were $14.75 \pm 7.75 \mathrm{~mL} / \mathrm{s}$ (range: 3.5 31.8 ) and $17.6 \pm 6.9 \mathrm{~mL} / \mathrm{s}$ (range: $6.6-34.9$ ), respectively. A paired t-test showed that measurements with smart UFM were significantly higher compared to conventional UFM $(p=0.03)$. The mean average urinary flow rates ( $Q$ ave) measured with conventional UFM and smart UFM were $3.8 \pm 2.6 \mathrm{~mL} / \mathrm{s}$ (range: 0.3 $-10.9)$ and $5.3 \pm 2.6 \mathrm{~mL} / \mathrm{s}(0.82-11.3)$ in male patients. In this group, Wilcoxon signed-rank test showed that $Q$ ave values measured by smart UFM were statistically higher compared to measurements with conventional UFM ( $Z=-2.773 ; p=0.006)$. Median measurements were 5.00 and $3.3 \mathrm{~mL} / \mathrm{s}$ for smart UFM and conventional UFM. In this group, Wilcoxon signedrank test showed that $Q$ ave values measured with smart UFM were statistically higher compared to measurements with conventional UFM(Z=-2.773; $\mathrm{p}=0.006$ ).

The mean maximum urinary flow rates ( $Q$ max) measured with conventional UFM and smart UFM were $19.0 \pm 13.1 \mathrm{~mL} / \mathrm{s}$ (range: $0.0-65.5$ ) and $24.6 \pm 12.5$ $\mathrm{mL} / \mathrm{s}$ (range: $2.8-53.7$ ) in the female patient group., respectively. In this group, Wilcoxon signed-rank test showed that $Q$ max values measured with smart UFM were statistically higher compared to measurements with conventional UFM (-3.33; $p=0.001)$. Median measurements were 16.20 and $9.3 \mathrm{ml} / \mathrm{s}$ for smart and conventional UFM, respectively. The mean $Q$ ave values measured with conventional and smart UFM was $5.3 \pm 4.6 \mathrm{~mL} / \mathrm{s}$ (ranging from 0.3-16.3) and $7.2 \pm 6.7 \mathrm{~mL} / \mathrm{s}$ (ranging from 0.5-51.6) in the girls. Wilcoxon signed-rank test showed that $Q$ ave values measured by smart UFM were statistically higher compared to measurements with conventional UFM $(Z=-1.98 ; p=0.47)$. Median measurements were 6.7 and $4.0 \mathrm{~mL} / \mathrm{s}$ for smart and conventional UFM.
In the boys group, respectively, there was a weakly positive correlation between these two measurements for $Q$ max and for Qave $(r s(8)=.383$, $\mathrm{p}=.001$ and $\mathrm{rs}(8)=.320, \mathrm{p}=.041)$. In the girls group, there was a moderate positive correlation between conventional and smart UFM measurements for $Q$ max and weak correlation for Qave measured with $(\mathrm{rs}(8)=.432, \mathrm{p}=.001$ and $(\mathrm{rs}(8)=0.293, \mathrm{p}=.025)$. Correlation graphics for conventional and smart UFM in terms of Qmax and Qave was shown in Figure $2 a$ and $2 b$.

\section{DISCUSSION}

In this study, the comparison between conventional and smart uroflowmetry in both genders was performed. The $Q$ max and Qave values were found to be significantly higher in the measurements with smart UFM compared to conventional UFM. Moreover, the Bland-Altman plot tests showed that most of the data points were between the level of confidence suggesting these two methods were in acceptable limits comparing to each other. According to our knowledge, this was the first study comparing these two test methods in Turkish children in the English literature.

In our study, $Q$ max and $Q$ ave values for girls were found to be higher than boys in both smart and conventional UFM. The flow rates of girls and boys were reported to be similar when the voided volume was less than $100 \mathrm{ml}$ in the literature ${ }^{(16)}$. Other studies reported that mean values were found to be higher in girls compared to boys, especially in higher voided volumes ${ }^{(17,18)}$. The higher mean maximum and average urine flow rates in girls could be due to anatomic features, including the shorter urethra and possible toilet-training differences in the countries.

Uroflowmetry test is an essential test for evaluating bladder dysfunction, especially for toilet trained children or children older than five years ${ }^{(19)}$. In one study from Canada, including 524 children, it was reported that only in $12.8 \%$ of the patients tested, UFM was found to influence the treatment of the patients ${ }^{(20)}$. However, many factors are affecting the accuracy of UFM, especially in children. First of all, 
UFM should be performed in a private and quiet place, with minimal environmental factors interfering with the children's concentration. The position during UFM changes according to the gender, with boys voiding in a standing position and girls voiding in a sitting position with adequate foot support ${ }^{(4)}$. In our study, the Qmax and Qave values measured with smart UFM was significantly higher compared to conventional UFM. Since conventional UFM requires an operator or a nurse for performing the measurement, it can cause non-compliance of the patient. Patients can feel uncomfortable and embarrassed while voiding near someone, which could affect the UFM results.

Qmax and Qave measured with smart UFM were statistically higher compared to conventional UFM regarding both gender in our study, as mentioned above. However, mean Qmax and Qave values measured by smart UFM are measured higher in the girls' group compared to boys group comparing conventional UFM. Moreover, the Bland-Altman plot tests revealed that majority of the patients who were outside or above the $95 \%$ level of confidence are girls, suggesting that they are more likely to demonstrate discordant values with conventional UFM. This finding could be due to the girls being much shyer and affected by the presence of someone in the room while urinating. Thus the smart UFM had much more major effect for higher Qmax, and Q ave achieved.

This study has limitations due to its design. First of all, data, including Qmax and $Q$ ave, were collected retrospectively from the medical files. In this study, we did compare the unadjusted raw data from two different UFMs and did not investigate the difference of the test in the decision-making tree. Moreover, the current study had mainly focused on the comparison between smart and conventional UFM on patients suspected of having urodynamic problems. For this reason, further studies require for children with normal urodynamic physiology. The Smart UFM is working on the principle of selfguidance of the child and gives verbal instructions for completing tests, and we did not have an instrument for measuring the compliance of the children to the quick UFM tests.

In conclusion, the new smart "self-directed outpatient uroflowmetry" which might ensure patient privacy, especially in girls had higher Qmax and Qave values compared to conventional UFM. Further large-scaled studies in children with normal urinary function should be performed to evaluate the clinical impact of the new smart uroflowmetry technique.

Ethics Committee Approval: SBI. Izmir Dr. Behcet Uz Kids Diseases and Surgery Training and Approval was obtained from the Research Hospital Ethics Committee (2019/313).

Conflict of Interest: None.

Funding: None.

Informed Consent: Obtained.

\section{REFERENCES}

1. Babu R, Gopinath V. Role of Uroflowmetry with electromyography in the evaluation of children with lower urinary tract dysfunction. Indian J Urol. 2015;31:354-7. https://doi.org/10.4103/0970-1591.166469

2. Barroso U, Jr., Nova T, Dultra A, et al. Comparative analysis of the symptomatology of children with lower urinary tract dysfunction in relation to objective data. Int Braz J Urol. 2006;32:70-6. https://doi.org/10.1590/S1677-55382006000100013

3. Van Batavia JP, Combs AJ. The Role of Non-invasive Testing in Evaluation and Diagnosis of Pediatric Lower Urinary Tract Dysfunction. Curr Urol Rep. 2018;19(5):34. https://doi.org/10.1007/s11934-018-0784-1. Review.

4. Chang SJ, Yang SS. Do uroflowmetry and post - void residual urine tests necessary in children with primary nocturnal enuresis? Int Braz J Urol. 2018;44(4):805-11. https://doi.org/10.1590/s1677-5538.ibju.2017.0464

5. Bauer SB, Nijman RJ, Drzewiecki BA, Sillen U, Hoebeke P; International Children's Continence Society Standardization Subcommittee. International Children's Continence Society standardization report on urodynamic studies of the lower urinary tract in children. Neurourol Urodyn. 2015;34(7):640-7.

https://doi.org/10.1002/nau.22783. Epub 2015 May 21

6. Van Batavia JP, Combs AJ, Fast AM, Glassberg KI. Use of noninvasive uroflowmetry with simultaneous electromyography to monitor patient response to treatment for lower urinary tract conditions. J Pediatr Urol. 2014;10:532-7. https://doi.org/10.1016/j.jpurol.2013.11.015

7. Yang SS, Chang SJ. Uroflowmetry in Children can be Simply Classified as Normal or Abnormal Pattern. Urol Sci. 2010;21:142-4 https://doi.org/10.1016/S1879-5226(10)60031-0

8. Yang SS, Chiang I, Chang SJ. Interpretation of uroflowmetry and post-void residual urine in children: fundamental appro- 
ach to pediatric non-neurogenic voiding dysfunction. Incont Pelvic Floor Dysfunct. 2012;6:9-12.

9. Samijn B, Van Laecke E, Vande Walle J, et al. Uroflow measurement combined with electromyography testing of the pelvic floor in healthy children. Neurourology and Urodynamics. 2019;38:231-8. https://doi.org/10.1002/nau.23836

10. Rosier P, Schaefer W, Lose G, et al. International continence society good urodynamic practices and terms 2016 :urodynamics, uroflowmetry, cystometry, and pressure-flow study. Neurourol Urodyn. 2017;36:1243-60. https://doi.org/10.1002/nau.23124

11. Austin PF, Bauer SB, Bower W, et al. The standardization of terminology of lower urinary tract function in children and adolescents: update report from the standardization committee of the International Children's Continence Society. Neurourol Urodyn. 2015;191:1863-5. e13.

12. Drzewiecki BA, Bauer SB. Urodynamic testing in children: indications, technique, interpretation and significance. J Urol. 2011;186(4):1190-7. https://doi.org/10.1016/j.juro.2011.02.2692. Epub 2011 Aug 16. Review.

13. Babu R, Gopinath V. Role of uroflowmetry with electromyography in the evaluation of children with lower urinary tract dysfunction. Indian J Urol. 2015;31(4):354-7. https://doi.org/10.4103/0970-1591.166469

14. Chase J, Austin P, Hoebeke P, McKenna P; International Children's Continence Society. The management of dysfunctional voiding in children: a report from the Standardisation
Committee of the International Children's Continence Society. J Urol. 2010;183(4):1296-302.

https://doi.org/10.1016/j.juro.2009.12.059. Epub 2010 Feb 19.

15. Bland JM, Altman DG. Statistical methods for assessing agreement between two methods of clinical measurement. Lancet. 1986;1:307-10. https://doi.org/10.1016/S0140-6736(86)90837-8

16. Szabo L, Fegyvrneki S. Maximum and average urine flow rates in normal children the Miskole's nomograms. Br J Urol. 1995; 76:16-20. https://doi.org/10.1111/j.1464-410X.1995.tb07824.x

17. Gutierrez Segura C: Urine flow in childhood: a study of flow chart parameters based on 1,361 uroflowmetry tests. J Urol. 1997;157(4):1426-8. https://doi.org/10.1016/S0022-5347(01)65010-9

18. Kajbafzadeh AM, Yazdi CA, Rouhi O, Tajik P, Mohseni P. Uroflowmetry nomogram in Iranian children aged 7 to 14 years. BMC Urol. 2005;5:3. https://doi.org/10.1186/1471-2490-5-3

19. Yoo S, Lee Y, Park J, Cho SY, Cho MC, Jeong H, et al. Voided volume $<150 \mathrm{~mL}$ on initial uroflowmetry in men with storage symptoms: Is it an unreliable test result or a sign of severe storage symptoms? PLoS One. 2019;14(1):e0207208. https://doi.org/10.1371/journal.pone.0207208. eCollection 2019.

20. Alyami F, Farhat W, Figueroa VH, Romao RL. Utility and costeffectiveness of uroflowmetry in a busy pediatric urology practice. Can Urol Assoc J. 2014;8(9-10):E615-8. https://doi.org/10.5489/cuaj.2190 